\title{
Host ikke i boken
}

For noen år siden, da bokserien Fifty Shades toppet bestselgerlistene i både inn- og utland, fant to belgiske forskere spor av herpes og kokain i biblioteksbøker. Nesten hundre år tidligere, i Tidsskriftet nr. 13/1916, ble det omtalt en undersøkelse av hvorvidt bøker som har vært håndtert av tuberkulosepasienter kunne være smittefarlige. Forskerne hadde fått oppdraget av «et stort offentlig bibliotek», og selv om det ikke eksisterte noe kjent tilfelle av smitte på denne måten, mente de at det var teoretisk mulig ut fra Flügges teori om dråpesmitte. De ønsket å gjøre undersøkelsene «i overensstemmende med, hvad der foregaar i det daglige liv», og altså ikke dyrke frem bakteriene. Det første steget i prosessen var dermed å få alvorlig syke pasienter til å hoste på papirark, og deretter la dem ligge i henholdsvis to og 31 dager før friske marsvin ble utsatt for den eventuelle smitten. Konklusjonen her var at smittefaren var svært lav. Men hva hvis pasientene slikker på fingrene når de blar i bøkene? I to forskjellige fors øk unders økte forskerne henholdsvis konsekvensen av å smøre «sterkt bacilleholdig sputum, blandet (...) med meget spyt» ut på et rent papir, og å la syke pasienter slikke på fingrene sine og stryke dem over papir. Resultatet her var at smitten hadde lettere for å spre seg ved å bli smurt på sidene fremfor gjennom at leseren slikker fingrene - men smittefaren var fortsatt lav. Og den gode nyheten var at de ved å opphete boksidene «med damp til $95^{\circ} \mathrm{C}$ i $1 / 2$ time» tok knekken på den lille smittefaren de fant. Under følger forfatternes konklusjon og forslag til tiltak (Tidsskr Nor Lægeforen 1916; 36: 614-8).

\section{Om faren for utbredelse av tuberkulosesmitte ved bøker.}

Henry Kenwood og Emily Dove

Forff. trækker følgende slutninger av sine forsøk: 1. Der er sandsynligvis ingen fare forbundet med utlaan av bøker, som nylig er læst av tæringspatienter, medmindre bøkerne er tydelig tilsølet, og selv da er faren liten.

2. Man bør imidlertid søke at beskytte publikum mot denne fare, selv om den er liten. Dette kan ske ved desinfektion eller ved at «lægge bøkerne i karantæne» i særskilte rum i en maaned. Rummet bør desinficeres av og til. Er bøkerne meget skidne, bør de fjernes fra cirkulation.

3. En lap med følgende instruktion bør sættes paa alle bøker, som utlaanes: a) Host ikke i boken. Hold altid lommetørklædet for munden, naar du hoster. b) Væt ikke fingrene med spyt for lettere at vende bladene i boken. Hænderne bør altid være tørre og rene. c) Hold altid boken lukket, naar den ikke læses. 4. Fuktig varme er et godt middel til at destruere tuberkelbaciller. Temp. bør være henimot $100^{\circ} \mathrm{C} ; 1 / 2$ times opvarmning er tilstrækkelig.

Forff. vil fortsætte sine eksperimenter for at se, om fugtig varm luft kan brukes til desinfektion ogsaa av pent indbundne bøker uten at gjør dem skade.

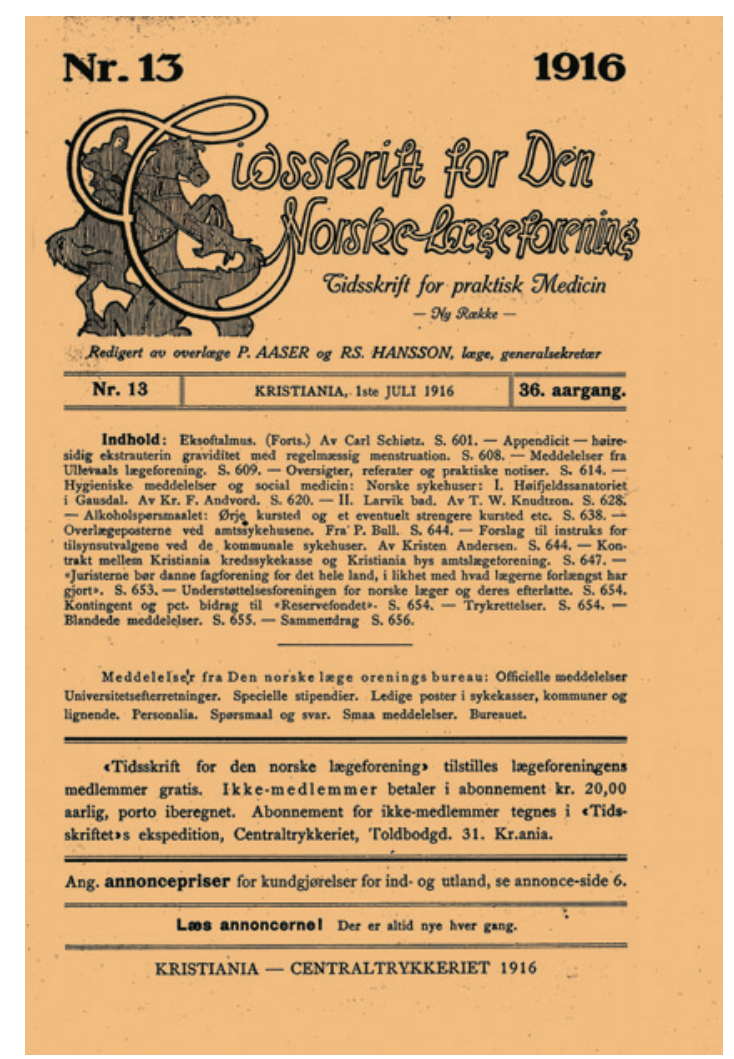

